\title{
Non-Performing Loan and Financial Stability of Banking Industry in Pakistan
}

\author{
FAZLI RAHMAN KHAN \\ MS Scholar at Bacha Khan University, Charsadda. \\ Dr. MUHAMMAD NISAR KHAN \\ Corresponding Email: nisarmgnt@bkuc.edu.pk \\ Lecturer in Finance at Bacha Khan University, Charsadda. \\ Dr. SAIMA UROOGE \\ Assistant professor of Economics, Islamia College University, Peshawar.
}

\begin{abstract}
The objectives of this study to assess the state of financial stability of commercial banks in Pakistan and then estimate how good, bad and worst economic conditions would influence the stability. Our design of the study is a mix of techniques. Pakistan have not experienced financial crisis due to some shocks, therefore stress events and its effects not included in design. This study examines the effect of nonperforming loans on financial stability empirically. Based on the above premise, this thesis investigates the association of financial stability with non-performing loans for all commercial banks of Pakistan for the period of 2014-2018. The study used the 27 commercial banks having 162 bank year observations. The study measured of financial stability (FS) through the financial leverage ratio and liquidity ratio using the common effect model. For the non-performing loans this study uses the non-performing loan ratio. Using secondary data that is panel in nature and applying panel data models for analysis, the study finds out that non-performing loans negatively associated with financial stability of commercial banks in Pakistan.
\end{abstract}

Keywords: Loan, Finance, Banking, Stability, Pakistan.

\section{Introduction}

A bank is financial institution that accepts the deposit from the public and creates a demand deposit while simultaneously making loans, Lending activities can be performed either directly or indirectly through capital markets. Banks play very important role in the economy of the country. Banks are special driver of a country for the development of the economy as they are providing the blood to the economy in the form of the lending to the deficit units (Polo, 2007). The banking system operations are quite complex, because banks struggle to gradually develop to changing customer needs and expectations and introduce latest technologies (Arun \& Turner, 2003). This is common in many developing countries where the institutional environment is weak and shareholders have less information (Burki \& Ahmad, 2010). In Pakistan banking sector was dominated by state own banks, lack of good governance and many other factors like lending policy of banks, lack of technologies, shareholders protections etc. Hurt this sector badly and banks generate huge of loans. Aim of this study to examine the role of non-performing loans (bad debt) on commercial banks financial stability in Pakistan.

Symss et al., (2018) report that non-performing loans is an asset of the banks. Non-performing loans (NPLs) also called non-performing assets (NPAs). This kind of loans refers to those that were unable to repay and its balance remains the same in a long period of time. Simply NPLs is a loan when a payment is 
late for 90 day or a payment which is not according to the agreement or according to the contract and is classified as non-performing loans. NPLs reflect some aspects of commercial bank's financial stability and performance. Level of NPLs can be considered as the best indicator for stability of banking sectors. There are different ways to measure NPLs, among them some are quantitative and some are qualitative. These two were mostly used in the banking sectors. Quantitative is when bank can calculate the probability of default. Qualitative is only helping in the estimating the number. This is a clear term for contracts between shareholders and commercial banks, maximizing commercial banks value for managers and management. The task of the head of the company here is a special case of directors and special officials of the commercial banks in Pakistan. Main objective of study is to examine effect of NPL on Banks financial stability in Pakistan.

This study focuses on the impact of NPLs on FS of commercial banks in Pakistan. Although much research has been conducted on the same subject, little research has been conducted in Pakistan on the causes and consequences NPLs (bad debts) on the FS of Pakistan commercial banks. Therefor this research tries to investigate the association among NPL and stability of Banks in Pakistan. Most of NPL literature that NPL effect stability of Banks.

Most of the prior literature reveals that this association is thoroughly investigated in develop countries but there still exist a gap in developing countries, literature is scare in emerging economies. Thus, this study aims to examine the relationship between NPLs, and FS in banking sector of Pakistan.

\section{Main Objective}

This research exmine the effect of NPLs on commercial banks FS. The study uses all commercial banks in Pakistan as population. On the basis of convenience sampling technique, a sample of 27 banks are selected for analysis for the period of 5 years 2014-2018. A bank is selected if their data for all variables is available. Hence, the total bank-year observations of study are 162. Data is collected from respective websites of commercial banks of Pakistan, annual reports of commercial banks for the period of 20142018.

The study uses NPLs measure through NPL ratio, as independent variables while FS is dependent variable is measure through the financial leverage ratio and liquidity ratio by using the OLS method. This study also uses control variables for size and age of commercial banks of 2014-2018. As nature of the data is panel. Therefore, Panel Models specifically common effect model is applied on the data. The study finds that NPLs, is statistically negative significant with FS of commercial banks in Pakistan.

\section{Review of Literature}

This part of paper presents the prior theoretical and empirical literatures. NPL is extensively studied and therefore sufficient literature from the developing countries is available. Based on studied literature this paper examines the non-performing loans. This study refers to the effects of non-performing loans on financial stability of commercial banks in Pakistan.

\section{Financial Stability}

John et al. (2016) investigate the role of CG effects the banks stability in US and international settings. This study discuss how banks FS affects by the deposit insurance, leverage, regulation and banks governance, evaluate the banks governance from the equity value, enterprise value and social objectives, also include that how banks governance are differed from the manufacturing firms. Furthermore, study figure out managerial incentives in banks and their implication for the stability of banks. This study finds out the result that high leverage of banking institutions give rise to a trade-off between strengthening equity governance and increase enterprise value. The banks risk choices might also go against the social 
objectives of a stable financial system. Paper also provide the policies for implications for the banks regulation, top-management composition in banks and directives for design of governance in banks. The research discusses implications for the direct regulation of banks and regulation of banks governance. Furthermore, provide the guidance for board independence, board size, board composition and incentive features for the top-management.

Burki and Ahmad (2010) investigate the performance and stability of the State-Owned Banks (SOB) in Pakistan. This study find out that private banks demonstrate highest level of cost efficiency, followed by foreign, and State-Owned Banks. Privatized and restructured banks suffer from efficiency losses in years following privatized and restructuring, but improved performance if they adjust. Although small and weak banks are selected for $\mathrm{M}$ and $\mathrm{A}$, but to follow ownership change they increase efficiency. If the present trends continue the reformed banks are likely to hold on to efficiency gains in the near future. The winner from the reform are privatized banks and private banks selected for $\mathrm{M}$ and $\mathrm{A}$, who exploit new profitmaking opportunities.

Rehmans and Mangla (2010) investigates and compared the FS of conventional and Islamic banks in Pakistan. Five Islamic banks, five small commercial banks and five large commercial banks using the Zscore for banks operating in the Pakistan. Finely conclude that based on the average values of ratios and empirical analysis of statistical tools, it is found that Islamic banks are more stable than both large and small conventional banks but their return on assets (ROA) are comparatively smaller than large conventional banks, however, it is large than small conventional banks.

Huang and Song (2004) this paper test the hypothesis through the trade-off model and pecking order model. Results show that financial leverage increases with increase in the firm size. Researchers also state that ownership structure affects financial/leverage. The features of capital structure for Chinese listed companies are better explained by the trade-off model rather than pecking order hypothesis.

Chen et al. (2011) determine that in the last 20 years there have been several banks failures worldwide. The financial difficulties in most of these countries are associated with high level of bad credit, bad governance and poor credit policies. These events are said to reflect a decline in the quality of credit lines. A couple with constant reclassification of banking activities. Furthermore, the CG factors affect the banks failures and FS.

Anginer et al. (2018) mention that larger banks earn more benefits from the greater protection by financial safety and stability net on the account of the to-fail-to-big status and on the basis of an international sample. furthermore, this study examines the relationship among risk taking and banks ownership and find that the higher the cash flow, the greater the owner of the banks, the greater is the risk, further capitalization rates favorable to shareholders and CG are negatively correlated. CG, examine how a financial provider of a bank can get a return on investment.

Qureshi and Abbas (2019) investigate effect and consequences of CAMEL ratios, bank size, type of banks and governance structure on the financial stability and performance of banks in Pakistan banking sector. The study compares the Islamic and traditional banks of Pakistan, in which two pure Islamic banks and fifteen traditional banks in Pakistan. This study finds out that except government structure all above variables are highly significantly assessing the stability and performance of banks. The finding reveals significant implications for policymaker in assessing Islamic and traditional banks stability and performance in Pakistan, further ascertaining the direction of a future baking system in Pakistan.

Raza et al. (2020) investigate the impacts of CG on FS and performance of the privatize firms in Pakistan. Overall result show that independent directors has no significant impact on firm's stability, CEO duality has partial significant impact on firm performance and stability, board size did not show any significant 
relationship with the firm performance and stability, firm age has shown significant result, firm size has significant result in respect of all measure of firm's stability.

Klein (2013) investigate determinants of the NPLs in Eastern and South Eastern Europe (ESEE). This study uses the quarterly data of the nine countries. Apply the GMM in order to examine the possible relationship among the variables and error term of the given model. The study finds out that economic growth has pivotal role in the NPLs development, study also figure out that stock index is the indicator of the economic development and affect the NPLs.

Beck et al. (2013) examine for NPLs economic growth have a positive relationship in form of the real GDP growth. The study figures out that lending in foreign currency and exchange rate negatively affect the NPLs. Finely the study concludes that NPLs is increase with stock price when stock price is drop. After some time, research also reach to this point in another paper in 2013 by used the dynamic panel estimation methods. Another place of (Cerulli et al. 2017) figure out the three main factors of the macroeconomic determinants which effect on the NPLs and GDP growth, high interest rate and growth in the judicial system. High interest rate of the loans effects the power of lending of the individual to pay back the loans to the institutions, which also impact on the NPLs.

Cucinelli (2015) analyze the data of the 488 listed and unlisted Italian banks of commercial and corporate banks, she examines the bank's lending policy, credit risk and implementation credit policy. Her paper show that credit risk or NPLs is strongly correlated with the lending behaviors of the banks. Increase in NPLs reduce the risk tolerance of the banks. She also figures out that there is no any indication of differences of commercial and corporate banks during the financial crisis, another place she mentions the NPLs Unlikely-to-Pay (U-t-P) performing and NPLs.

Dimitrios et al. (2016) in this study investigate the factors which affect the European banks and factors of the NPLs in the core and periphery countries, the study finds out that NPLs are different in the both countries core and periphery in euro area. In other words, study figure out quality of management in term of ROA and ROE and moral hazard loans to deposit significantly effect NPLs of the core and periphery countries. At the lost research conclude that in the periphery countries are more affect by the interest rate margin and fiscal consolidation core countries are affected by credit to the GDP.

Do et al. (2020) investigate the relationship between the NPLs and banks profitability and stability in the financial market. To examine the relation between the NPLs, profitability and stability of banks, the paper empirically find out that when the rate of NPLs increase, the bank's ROA will decrease, meaning that the bank's profitability will be lower, furthermore in case of Vietnam, loans to deposits rate and growth of GDP both have an impact on the bank's performance and stability while banks size doesn't matter. Ozili (2019) investigate the effect of NPLs on financial stability of banks, using the worldwide sample. This study finds two indicators, foreign banks and financial intermediations. These two are positively associate with NPLs among the determinants of NPLs, banks efficiency, loan loss coverage ratio, competition and bank stability are inversely associated with NPLs. Also find out that NPLs are positively effect with bank crisis and concentration, and NPLs are negatively affect the regulation capital and liquidity experience.

On the basis of studied literature, the following hypotheses are developed

\section{Hypothesis of the Study}

Main hypotheses of the study are as follows.

H1: non-performing loans significantly effect bank's financial stability.

H2: size of the bank significantly affects the banks financial stability.

H3: age of the firm significantly affects the bank financial stability 


\section{Framework of the study}

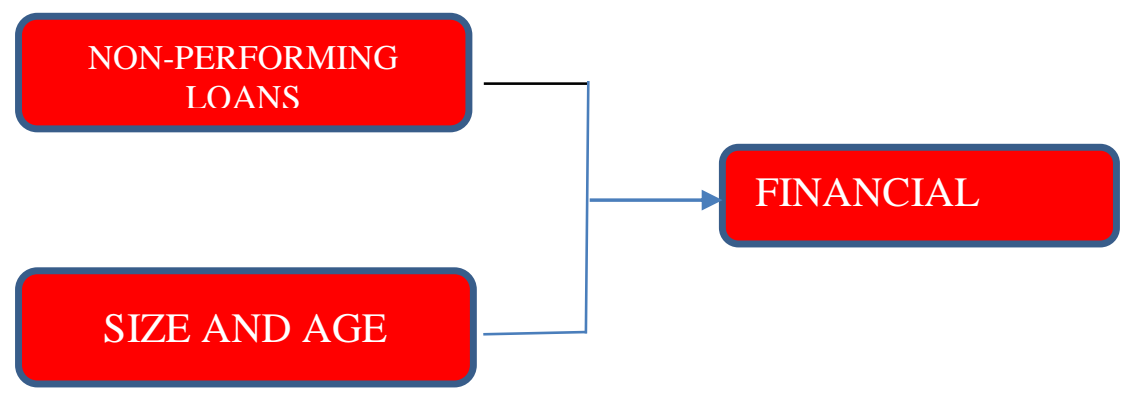

\section{Research Methodology}

\section{Data Source and Sample Selection}

This study selects all commercial banks of Pakistan as population. Commercial banks are sample extract from of all commercial banks in Pakistan. Sample consist on the 27 commercial banks of Pakistan for period of 2014-2018. Thus, the total banks year observations are 162.

All data is secondary and panel in nature. Data for the all variables are downloaded from the websites of included commercial banks. Furthermore, for collecting the data use the financial statements in annual reports of each commercial banks for selected indicators of the variables. Sample selection criteria is differ from other studies in Pakistan. Different combination of variables set up for the effect on the FS in the banking sectors, either banks are commercial or non-commercial banks. Different studies used different techniques, samples, period of sample for collecting the data of for NPLs and FS. For example, (Symss et al., 2018) used short period for the collecting the data of NPLs. Demirguc-Kunt et al. (2003) report the techniques and taking long period of sample for financial stability and (MWANZIA \& OCHANDA., 2017).

\section{Data Analysis Techniques}

This study uses different models to analyze data for results accuracy. Descriptive statistics, Correlation analysis and Panel regression analysis were used to investigate the effect of NPLs, on FS after using the controlling for size and age.

\section{Multivariate Analysis}

This study examines the effects of NPLs on FS of commercial banks in Pakistan, different models are used. Respective models are as under;

$$
\mathrm{FS}=\alpha_{0}+\beta_{1}(\mathrm{NPLs})+\beta_{2}(\mathrm{CV})+\mu_{\mathrm{i}}
$$

Where FS is represented the financial stability is as dependent variable in the study, using the leverage ratio and liquidity ratio, which are leverage ratio is measured as debt to equity ratio and liquidity ratio is measure through current assets to current liabilities (Demirguc-Kunt et al., 2003); while NPLs is non-performing loans which adopted by Symss et al., (2018) who developed it for a short period of time but in this study used for long period as 2014-2018, for period of five years, using the NPLs ratio method as measured by NPLs to total loans. Furthermore, CV represented the control variable which are size and age, size as measure through logarithm of total assets of year. 


\section{Results and Conclusion}

Descriptive statistics of the data portrays the characteristics of the data. Results includes correlations, as well as regression analysis. Panel regression models were used for testing hypothesis and investigate the effects of non-performing loans on financial stability. It is reported that the dependent variable FS measured through the financial leverage ratio and liquidity ratio (Demirguc-Kunt et al., 2003), while NPLs through non-performing loan ratio (Symss et al. 2018).

\section{Descriptive Analysis of the Study}

This study takes 27 commercial banks in Pakistan as sample for period of 2014-2018. The total observations of study are 162. Below table present descriptive statistics of variables. Financial leverage ratio and liquidity ratio measure the FS. These results show all the indicators of the FS are centrally placed i-e mean and median of all the FS measure are closely observe. Mean of the financial leverage is 12.178 while the median is 11.765 . Similarly, liquidity ratio mean is 1.110 while median is 1.098 , which almost similar. Skewness and Kurtosis represent that these indicators are normally distributed. Moreover, these value on average represent that commercial banks are mostly effective in all Pakistan. Values are 75 percent of the efficiency, $1(100 \%)$. Results revealed that commercial banks are stable financially in Pakistan in commercial banking market.

\begin{tabular}{|llllll|}
\multicolumn{7}{c}{ Table 1: Descriptive Statistics } \\
\hline & FINANCIAL_LEV & LIQ_RATIO & NPL & SIZE & AGE \\
\hline Mean & 12.178 & 1.110 & 0.109 & 19.924 & 24.432 \\
Median & 11.765 & 1.098 & 0.098 & 19.913 & 25.500 \\
Maximum & 28.247 & 1.249 & 0.310 & 22.391 & 45.000 \\
Minimum & -0.995 & 1.001 & 0.001 & 17.739 & 4.000 \\
Std. Dev. & 6.550 & 0.051 & 0.067 & 0.893 & 8.708 \\
Skewness & -0.137 & 0.289 & 0.481 & 0.250 & -0.220 \\
Kurtosis & 2.765 & 2.617 & 2.716 & 2.545 & 2.571 \\
Observations & 162 & 162 & 162 & 162 & 162 \\
\hline
\end{tabular}

FINANCIAL LEV is leverage ratio and LIQ RATIO is liquidity ratio used to measure the financial stability, NPL non-performing loan measured through NPL ratio, size and age are control variables.

NPLs is independent variable in the study. The score of selected commercial banks sample ranges from maximum 0.310 to minimum 0.001 with mean is 0.109 , median is 0.098 and standard deviation is 0.067 , means that dispersion of data is minimum. Moreover, mean and median of NPLs is closer to each other. It's confirmed from the skewness and kurtosis that NPLs value is in the acceptable ranges and normality distributed.

Results show that control variables are centrally placed its can be seen from its values of mean, median and standard deviation with skewness and kurtosis. Control variables of the study are size and age as show in above table. How, let explain size and age, for example, mean of size is 19.924 and median is 19.913, standard deviation is 0.893 with range maximum 22.391 and minimum 17.739 , meaning that mean and median are closer to each other. Show that dispersion in the data is minimum. Second, age with mean, median and standard deviation are 24.432, 25.500 and 8.708 respectively, with range maximum 45.000 and minimum 4.000. Its standard deviation show that data is low disperse and mean median are closer to each other. Finely, control variables are in the acceptable range and normally distributed. 


\section{Correlation Matrix}

Correlation matrix check the relationship between variables. Table below show the association of variables. Multicollinearity among the explanatory variables can easily check through correlation matrix.

Table 2: Correlation Matrix

\begin{tabular}{|lllll|}
\hline & FINANCIAL_LEV & LIQ_RATIO & SIZE & AGE \\
\hline FINANCIAL_LEV & 1.000 & & & \\
LIQ_RATIO & 0.442 & 1.000 & & \\
NPL & -0.392 & -0.117 & & \\
SIZE & 0.183 & 0.116 & 1.000 & \\
AGE & 0.183 & 0.271 & 0.311 & 1.000 \\
\hline
\end{tabular}

FINANCIAL LEV is leverage ratio and LIQ RATIO is liquidity ratio used to measure the financial stability, NPL non-performing loan measured through NPL ratio, size and age are control variables.

All these results similar to the (MWANZIA \& OCHANDA., 2017), (Demirguc-Kunt et al., 2003), (Shleifer \& Vishny, 1997), (Barakao and Tower., 2007) and (Symss et al., 2018). Regarding the control variables size and age are positively correlated with FS measures.

The next section finds results for the data analyses basis of regression models in order to determine which of the model is suitable for data. Since the data panel in nature, study apply diagnostic tests for suitable model. First step, study presents results through diagnostic tests, tests for normality, heteroscedasticity and multicollinearity are given in the below.

\section{Model Specification}

If data not satisfying the OLS assumptions, then study use panel data analysis technique for investigation of NPLs effects on FS. Therefore, through model specification test study select the best model among pooled data, FEM and REM for testing hypothesis, similar to assumptions of OLS, Panel data techniques also require for diagnostic test, i-e F value/Chow test for pooled and FEM models, Hausman test for FEM and REM, and Breusch-Pagan LM test for REM and Pooled model (Breusch and Pagan, 1979), (Gujarati 2003) and (Hausman, 1978). The above table conclude as per selection criteria being refer to above table, that Pooled OLS is the suitable for analysis technique for this study.

Table No: 3

\begin{tabular}{|ll|}
\hline Model Specification Tests & Prob>chi2 \\
\hline Model-I FL with NPL & \\
Chow test for pooled versus FEM & \\
if p-value $\leq 0.05 \rightarrow$ FE & 0.1243 \\
Decision & Pooled OLS model \\
\hline
\end{tabular}

\section{Pooled OLS Model Results}

Tables below depicts the results of CEM to investigate the effect of NPLs and on FS for the period of 20142018. The study uses two proxies leverage ratio and liquidity ratio for the FS. These are already explained in details in the methodology section. 
TABLE 4: Dependent Variable: LIQ_RATIO

\begin{tabular}{|llll|}
\hline Dependent Variable: FINANCIAL_LEV & & & \\
\hline Variable & Coefficient & t-Statistic & Prob. \\
\hline C & -0.888 & -0.732 & 0.465 \\
NPL & -0.822 & -4.228 & 0.000 \\
SIZE & 0.882 & 2.190 & 0.040 \\
AGE & 0.276 & 5.372 & 0.000 \\
R-squared & 0.494 & & \\
Adjusted R-squared & 0.471 & & \\
F-statistic & 21.451 & & Prob. \\
Prob(F-statistic) & 0.000 & & 0.000 \\
Variable & Coefficient & t-Statistic & 0.025 \\
\hline C & 0.910 & 10.635 & 0.000 \\
NPL & -0.067 & -2.120 & 0.017 \\
AGE & 0.002 & 3.607 & \\
SIZE & 0.007 & 2.575 & \\
R-squared & 0.320 & & \\
Adjusted R-squared & 0.289 & & \\
F-statistic & 10.346 & & \\
Prob(F-statistic) & 0.000 & & \\
\hline
\end{tabular}

Financial Lev is leverage ratio and LIQ RATIO is liquidity ratio used to measure the financial stability, NPL non-performing loan measured through NPL ratio, size and age are control variables.

Below show results of the financial leverage with the other independent variables NPLs. In the table below financial leverage is negatively associated with leverage ratio. It means that leverage is statistically negatively significantly NPLs. In Table 4 liquidity ratio associated with the other independent variables NPLs. Table 4 shows that liquidity ratio is negatively associated with the NPL and results show control variables of size and age are also significant and expected directions as per theory. The all results in the Table 3 are related to earlier literature of NPLs, with financial leverage. Earlier literature is of (DemirgucKunt et al., 2003), (Barako and Tower 2017), (Symss et al. 2018) and (Mwanzia and Ochanda., 2017).

This research focuses on NPLs, CG systems to investigate their impact on FS using the dataset from 20142018 of commercial banks of Pakistan. The correlation matrix shows that NPLs, negatively associated with FS. Thus, its concluded from the table 3 and 4 that NPLs with FS.

Regarding control variables, result show that commercial banks size and age have a positive relationship with the indicators of FS which are financial leverage ratio and liquidity ratio. These results are consistent with previous studies, earlier literature is of (Demirguc-Kunt., et al 2003), (Barakao and Tower., 2017), (Symss et al. 2018) and (Mwanzia and Ochanda., 2017). 


\section{Conclusion}

This study empirically investigate association among NPLs with FS of commercial banks in Pakistan. Objectives of this study empirically test the associations of NPLs with FS of commercial banks in Pakistan. The objectives of this study to calculate the FS of commercial banks through the financial leverage ratio and liquidity ratio and to investigate the effects of NPLs on FS. The data is downloaded of 27 commercial banks of Pakistan in which seventeen are of private sector, nine are of public sector and one is foreign sector commercial bank for the years of 2014-2018 making total of 162 bank year observations. Data is collected from the annual reports of commercial banks websites for the measuring the included variables in the study. Panel secondary data were used. FS is measured through the financial leverage ratio and liquidity ratio, adopted from Demirguc-Kunt et al. (2003). NPLs is measured through the NPL ratio as used by the criteria of (Symss et al., 2018). This study extended the data period from 2014-2018 using the same criteria of above related papers. All data were collected from the financial statements in the annual reports of every commercial banks' websites. This study used the size and age as control variables of the commercial banks to avoid the biasedness in the results. Panel data were used to examine the relationship between the FS, NPLs. Specially, and study used the common effect model (CEM). Results of the study show that NPL is negatively associated with FS.

\section{References}

Arun, T., \& Turner, J. (2003). Financial sector reforms and corporate governance of banks in developing economies: the Indian experience. South Asia Economic Journal, 4(2), 187-204.

Anginer, D., Demirguc-Kunt, A., Huizinga, H., \& Ma, K. (2018). Corporate governance of banks and financial stability. Journal of financial Economics, 130(2), 327-346.

Barako, D. G., \& Tower, G. (2007). Corporate governance and bank performance: Does ownership matter? Evidence from the Kenyan banking sector. Corporate Ownership and Control, 4(2), 133-144.

Beck, R., Jakubik, P., \& Piloiu, A. (2013). Non-performing loans: What matters in addition to the economic cycle?

Burki, A. A., \& Ahmad, S. (2010). Bank governance changes in Pakistan: Is there a performance effect? Journal of Economics and Business, 62(2), 129-146.

Chen, F., Hope, O.-K., Li, Q., \& Wang, X. (2011). Financial reporting quality and investment efficiency of private firms in emerging markets. The accounting review, 86(4), 1255-1288.

Cucinelli, D. (2015). The impact of non-performing loans on bank lending behavior: evidence from the Italian banking sector. Eurasian Journal of Business and Economics, 8(16), 59-71.

Demirguc-Kunt, A., Laeven, L., \& Levine, R. (2003). Regulations, market structure, institutions, and the cost of financial intermediation. Retrieved from

Dimitrios, A., Helen, L., \& Mike, T. (2016). Determinants of non-performing loans: Evidence from Euroarea countries. Finance research letters, 18, 116-119.

Do, H., Ngo, T., \& Phung, Q. (2020). The effect of non-performing loans on profitability of commercial banks: Case of Vietnam. Accounting, 6(3), 373-386.

Huang, S. G., \& Song, F. M. (2004). The determinants of capital structure: Evidence from China. CHINA ECONOMIC QUARTERLY-BEIJING-, 3, 395-414.

John, K., De Masi, S., \& Paci, A. (2016). Corporate governance in banks. Corporate Governance: An International Review, 24(3), 303-321.

Klein, N. (2013). Non-performing loans in CESEE: Determinants and impact on macroeconomic performance: International Monetary Fund.

Mwanzia, D. M., \& Ochanda, J. O. (2017). Effect Of Corporate Governance On The Financial Stability Of The Banking Industry In Kenya. The stratigic journal of business and change managment, 4(20)(October 2017), 367-384.

Ozili, P. K. (2019). Non-performing loans and financial development: new evidence. The Journal of Risk Finance.

Polo, A. (2007). Corporate governance of banks: the current state of the debate. Available at SSRN 958796. 
Qureshi, M. H., \& Abbas, K. (2019). Performance Analysis of Islamic and Traditional Banks of Pakistan. International Journal of Economics, Management and Accounting, 27(1), 83-104.

Symss, J., Saradhi, V. R., \& Nehra, P. (2018). Determinants of non-performing assets in Indian banking sector. The Management Accountant Journal, 53(7), 91-98.

Raza, H., Gillani, S. M. A. H., Ramakrishnan, S., Gillani, S. M. A. H., \& Imran, M. (2020). Non-systematic Review of Financial Sustainability and Financial Distress. International Journal of Psychosocial Rehabilitation, 24(06).

Rehmans, R., \& Mangla, I. U. (2010). Corporate governance and performance of financial institutions in Pakistan: A comparison between conventional and Islamic banks in Pakistan. The Pakistan Development Review, 461-475.
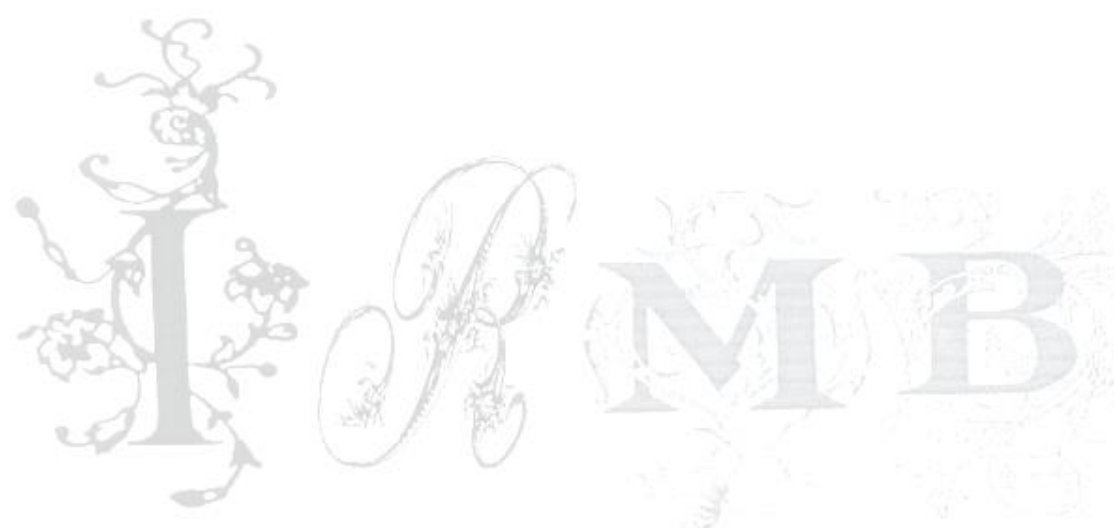